Robinson, M. B., and Roh, S. (2001). Crime on campus: A survey of space users, Crime Prevention and Community Safety: An International Journal 3(4): 33- 46. Original published and copyrighted version by Palgrave Macmillan (ISSN: 1743-4629). DOI:10.1057/palgrave.cpcs.8140104

\title{
Crime on Campus: A Survey of Space Users
}

\author{
Matthew Robinson and Sunghoon Roh
}

\section{INTRODUCTION}

It has long been asserted that if people knew why crime occurred, it should be easier to prevent, because we could focus prevention efforts on those factors that correlate with crime in certain people (Bohm, 2000). Similarly, if we knew where crime was most likely to occur, it should also be easier to prevent, because we could focus prevention efforts at those places where crime is most likely to occur (Rengert, Mattson, and Henderson, 2001).

While neither approach - focusing on people or places - is necessarily superior to the other, it is fair to conclude that the place-specific approach has led to far more effective crime prevention techniques in efforts implemented thus far (Paulsen and Robinson, 2004). In this chapter, we utilize the place specific approach by examining police crime statistics at a university campus in the Southeast United States. Our primary goal is to identify the places that host the most crimes, as reflected in campus crime data, in order to determine why some places have many crimes known to the police while others have few or none. Another goal is to suggest place-specific crime prevention strategies for those places that generate the most crime. 
Previous studies of the same university campus have shown that there is very little serious criminal activity on campus; students, faculty, and staff do not feel there is a "crime problem" on campus; there are low levels of fear of crime and perceived crime risk on campus; and the campus is rated as highly attractive and aesthetically pleasing (Robinson and Mullen, 2001; Mullen, Robinson, and Paulsen, 2001). While these previous studies of the university campus have been useful to policy-makers in various ways - including demonstrating the high level of safety on the campus and identifying at least one significant crime problem (i.e., underage alcohol use and illicit drug use) - the main limitation of the previous studies is that they did not directly address spatial aspects of crime on the campus. That is, the studies did not address where crimes most occur and what might explain the spatial variation on campus. Our current study attempts to overcome this weakness.

\section{LITERATURE REVIEW}

The literature on campus crime is sparse. A recent search utilizing the database, Criminal Justice Periodicals Index, found 115 articles on campus crime, but almost none of them were published in refereed academic journals, and only a handful were published since 2000 . Thus, there has been very little rigorous research on campus crime.

As this edited volume shows, campus crime research addresses issues such as criminal victimization on college and university campuses, fear of crime, perceptions of crime risk, lifestyles \& routine activities and criminal victimization, and potential crime prevention strategies that can be implemented to reduce or eliminate opportunities for criminality on campus (Brantingham and Brantingham, 1994; Brinkley Jr., and Laster, 2003; Bromley, 1994; Fisher, Cullen, and Lu, 1998; Fox and Hellman, 1985; Henson and 
Stone, 1999; Johnson and Sigler, 1996; Moriarty and Pelfrey 1996; O'Kane, Fisher, and Green, 1994; Richards, 1996; Siegel and Raymond, 1992; Sloan, 1992, 1994). Other articles deal with university obligations to respond to federal laws designed to increase safety on campus and inform the public about crimes on campus (Fisher and Sloan III, 1993; Sloan III, Fisher, and Cullen, 1997).

The previous studies demonstrate several notable realities about campus crime. First, crime against persons on campus is less common than that against the general population off campus. Second, the vast majority of crimes are property crimes while violent crimes are rare events. Third, the majority of students feel safe on campus even though perceptions of safety vary depending on student demographics and time/space correlates. Fourth, many campus crimes (especially property crimes) are not reported to the police, which evades a correct estimation of campus crime under the FBI's Uniform Crime Reports (UCR) system. Fifth, students' risky lifestyles (e.g. the use of alcohol and illicit drugs) increase their vulnerability to some forms of criminal victimization (Abbey, 2002; Abbey et al, 2001; Fisher et al, 1998; Robinson, 2004; Testa and Livingston, 1999; Wechsler et al, 1995; Wechsler and Wuethrich, 2003).

An additional reality of crime generally (that has not been widely documented on college and university campuses) is that crime tends to cluster in some areas. In these areas - known as "hot spots" of crime - a very large amount of crime occurs. In this study, we examine whether police statistics show that hot spots exist on one university campus. In the next section, we discuss the evidence of hot spots of crime both off and on campus. 


\section{Hot Spots}

Criminological research has identified places that host a disproportionate amount of crime (Brantingham and Brantingham, 1999; Sherman, Gartin, and Buerger, 1989; Sherman and Weisburd, 1995). A significant amount of research exists concerning hot spots of crime and their impact on criminal victimization. Specifically, research on hot spots has dealt with the crimes of burglary (Robinson, 1998a), auto burglary (Cochran and Bromley, 2002), liquor related crime (Block and Block, 1995), homicide (Block and Christakos, 1995; Block and Block, 1998), street gang violence (Block and Block, 1995), gun violence (Sherman and Rogan, 1995), disorderly behavior (Koper, 1995), and drug activity (Green, 1995; Weisburd, 1995; Weisburd and Green, 1995).

Common hot spots of crime include street blocks near bars (Roncek and Maier, 1991), entertainment districts (Cochran, Bromley, and Branch, 2000), casinos (Stitt, Nichols, and Giacopassi, 2003), some street segments in cities (Weisburd, Bushway, Lum, and Yang, 2004), and bus stops (Loukaitou-Sideris, 1999).

Only a few published studies exist within educational institution settings that explore physical environmental features of crime hot spots. For example, O'Kane et al. (1994) found that about $40 \%$ of all auto-related crime occurred on only $12 \%$ of campus street segments, which were easily accessible to major thoroughfares. Astor et al. (1999) showed that the majority of violent events in high schools were concentrated in spaces with no guardians, such as hallways, dining areas, and parking lots. Rengert and Lowell (2005) showed that hot spots even exist within buildings on a university campus.

These hot spot studies are limited in terms of crime type and study setting. This is a particularly glaring omission in hot spot research considering the amount of crime especially crimes against property that are most amenable to prevention efforts -- that 
occurs on college campuses in any given year. It is likely that there are hot spots of campus crime because the environmental factors that may account for hot spots are prevalent on college campuses (e.g., a large amount of targets that are often unguarded in some locations, making those targets more attractive to offenders).

There are at least three kinds of hot spots, each which potentially has a separate explanation (Clarke and Eck, 2006). First, crime generators attract "large numbers of people ... for reasons unrelated to criminal motivation" (e.g., shopping areas, transportation hubs, festivals, and sporting events). Here, crime is attributable to the "large number of place users and targets." Second, crime attractors are places that provide "many criminal opportunities that are well known to offenders" so that those "with criminal motivation are drawn to such locales" (e.g., prostitution and drug areas, entertainment spots). Third, crime enablers provide "little regulation of behavior at places" so that "rules of conduct are absent or are not enforced" (e.g., a parking lot with no attendant).

These three types of hot spots of crime can be theoretically explained by three perspectives: rational choice theory, routine activity theory, and crime pattern theory. According to rational choice theory, offenders engage in criminal acts only when they believe that the potential benefits outweigh expected costs by their criminal behaviors (Cornish and Clarke, 1986). The decision-making process is heavily affected by circumstances, situations, and opportunities because these factors should be considered to produce the net benefits expected from committing crimes.

Routine activity theory posits that crime requires three elements: motivated offenders, suitable targets (potential victims), and an absence of capable guardians (Cohen and Felson, 1979; Felson, 2002). The risk of crime increases when these three elements converge at the same place at the same time. In contrast, if any element is 
omitted, crime will not take place. Routine activity theory has been mostly said to explain crimes against property when the property is a suitable target and when it not protected by a capable guardian.

Finally, crime pattern theory combines rational choice theory and routine activity theory to explain geographic distribution of crime (Brantingham and Brantingham, 1993; Eck and Weisburd, 1995). Crime pattern theorists assume that most offenders seek their crime targets within the areas familiar to them. Serious offenders, just like the rest of us, engage in non-criminal activities in their daily lives. As they lead their routine activities they come to recognize desirable targets for crime. It is in these areas that crime would most frequently occur.

According to crime pattern theory, the criminal event is triggered by the presence of an opportunity that an offender comes upon in the course of a search (minimal or broad) depending on such factors as how well the offender knows the area). Nodes refer to where people travel to and from, paths are the main areas of travel in-between these nodes, and edges are the boundaries of areas where people engage in their activities (Clarke and Eck, 2006).

There have been numerous studies to explain campus crime with routine activity theory (Fisher and Wilkes, 2003; Mustaine and Tewksbury, 1998; Schwartz et al., 2001; Tewksbury and Mustaine, 2003; Volkwein, Szelest, and Lizotte, 1995; Wooldredge, Cullen, and Latessa, 1995). However, most of these studies focus on vulnerability to crime by focusing on victims' lifestyles rather than crime-prone spatial characteristics. This too can be conceived as a limitation to the body of literature on campus crime because physical features of the built environment play a large role in explaining where crime can cluster in hot spots, consistent with the crime prevention approaches of Crime 
Prevention Through Environmental Design (CPTED) and Situational Crime Prevention. In the next section, we discuss these two approaches to crime prevention.

\section{Crime Prevention Through Environmental Design and Situational Crime Prevention}

Alterations to the physical environment, such as increasing lighting, are examples of crime prevention through environmental design (CPTED). CPTED is aimed at "identifying conditions of the physical and social environment that provide opportunities for or precipitate criminal acts ... and the alteration of those conditions so that no crimes occur ..." (Brantingham and Faust, 1976: 289-292). CPTED is the management, design, or manipulation of the environment to prevent crime (Crowe, 1991; Robinson, 1999b). On the university campus, CPTED most commonly takes the form of blue-light trails, increased lighting, increased security mechanisms, and other target hardening devices (e.g., locks, alarms) (Robinson, 1999b).

CPTED is similar to "situational crime prevention." Situational crime prevention is aimed at eliminating opportunities for crime. It includes opportunity-reducing measures that are targeted at specific forms of crime and aimed at increasing "the effort and risks of crime and reduce the rewards as perceived by a wide range of offenders" (Clarke, 1992: 3-4).

There are at least 16 different ways to reduce opportunities for crime through situational crime prevention. The four major categories of situational crime prevention include: 1) increasing the difficulty of crime; 2 ) increasing the risks of crime; 3 ) reducing the rewards of crime; and 4) removing excuses for crime (Clarke, 2001)

While CPTED and situational crime prevention generally involve changing the environment to reduce the opportunity for crime, they are aimed at other outcomes as 
well. These include reducing fear of crime and perceptions of crime risk, increasing the aesthetic quality of an environment (e.g., by reducing conditions of incivilities) and increasing the quality of life for law-abiding citizens, especially by reducing the propensity of the physical environment to support criminal behavior (Robinson 1999b).

On many university and college campuses, where the risks of becoming victimized by serious violent crimes may be remote relative to large and mid-size cities, CPTED and situational crime prevention strategies may still be useful. Since alterations to the physical environment of campus may make people feel safer and less fearful, as well as increase the aesthetic quality of the surroundings, CPTED and situational crime prevention have a place on campus. Further, crime prevention efforts directed at hot spots of crime on campus should greatly reduce the amount of crime on campus, given that most crimes on campus (like off campus) likely occur in certain areas regularly. We believe that focusing on hot spots of crime will reduce the majority of crime on campus.

\section{HOT SPOTS: A CAMPUS CASE STUDY}

The current study is aimed at examining the most recent university police crime statistics (2004-2005) for the most common crimes on campus at a major comprehensive university in the southern United States. The goals of the study are to determine which places generate the most crimes known to the police and develop potential explanations as to why. We relate the findings to those from the previous studies of the same university campus and pay special attention to violations of drugs and alcohol since they are so often related to other forms of criminality. The explicit focus on spatial aspects of the campus make this study unique. 


\section{About the University}

The university of study - Appalachian State University - is located in Boone, North Carolina, a town with only approximately 14,000 residents (not counting students). The university is located in a county with only about 45,000 residents. Given these population figures, it is not surprising that the town and the county have below average crime rates and especially very little violent crime. This is because rates of street crime tend to be much higher in large and mid-size cities (Paulsen and Robinson, 2004). Thus, there is a wide perception that students at "Appalachian" are not threatened by the possibility of serious criminal victimization - either while on campus or while traveling throughout the town or county. Indeed, police statistics show that serious street crime is rare relative to larger towns and counties in the state and region.

Yet, recently and only thirteen months apart, two Appalachian students were murdered off campus in drug deals gone bad. These murders caused great concern on campus and significant attention was placed on criminal victimization of university students and crime prevention techniques that could be implemented on campus to protect students and put people's minds at ease. This study was in part motivated by these crimes.

Appalachian is major comprehensive public university with approximately 14,000 students, and is one of sixteen campuses of the state of North Carolina's university system. As Appalachian is located in Blue Ridge chain of the Appalachian Mountains, its campus is surrounded by mountains, trees, and park-like features (e.g., streams, boulders, etc.). Previous studies of the campus show that users of the campus generally rate the campus as highly attractive. The university is more than 100 years old and serves mostly residential students from the surrounding counties and larger state of North Carolina. 


\section{Study Methodology}

We contacted the University Police Department and requested the most recent campus crime statistics. The available data included the past two years of data (20042005) of calls for police service and police-initiated services for various types of crimes. The data were stored in police logs that were not computerized, not searchable, nor organized by crime type, location, date, time of day, or any other meaningful category. Thus, we had to sort through each daily log of crimes known to the police - hundreds of pages each with between one and as many as twenty crimes per page.

We then made a list of campus crimes for each major crime indicated in the data. For example, going chronologically through the data, we listed each theft by location, date, and time. Then, we counted the total number of each type of crime to determine which types of crimes were most common on campus. This process introduces the possibility of error, as some crimes were listed more than once (often to update the case with new evidence or the passage of time as cases were solved or closed due to a lack of evidence). It is also possible that we did not receive every page of data from the Department. Because of this, our counts of campus crimes may not perfectly match those ultimately compiled by the University Police Department.

The crimes of alcohol and illicit drug violations were often combined. For example, at one police response to a dorm, five citations were noted for alcohol use and illicit drug use. Since the police log did not specify how many citations were given for alcohol violations and how many were given for illicit drug violations, we were forced to count these violations as five alcohol violations and five illicit drug violations. We suspect this will tend to inflate the numbers of these offenses (although the data will still likely underestimate the true number of alcohol and illicit drug use violations on campus since most are not known to the police). 
An additional limitation of the police data is that most criminal victimizations are not included in police data. Nationwide, less than $40 \%$ of serious criminal victimizations are captured in police data (Robinson, 2005). Thus, this study of crimes known to the police does not likely capture the majority of criminal victimizations on campus.

However, in the absence of a university-wide victimization survey that addresses location of offenses, police data are the only data available for a study of campus crime locations. Further, most studies of place and crime utilize official crime statistics from police departments (Paulsen and Robinson, 2004).

With these limitations in mind, we next plotted campus crimes on maps of the university campus in order to identify those areas on campus that generated the most crimes as reflected in police statistics. Given that we did not have addresses for any of the crimes, including those that occurred inside dorms, academic buildings, and in parking lots, we could not plot exact locations of where the crimes occurred. Further, it was impossible to plot crimes that occurred on streets since the police data did not indicate where on streets the crimes occurred. The police data merely indicated from which streets calls originated (or on which street the offense occurred). The most common crime on streets was driving while intoxicated (DWI), and most of these were likely discovered by the police rather than initiated by a telephone call for service.

Given the nature of criminal victimization on campus, it was impossible to calculate criminal victimization rates based on the number of potential victims in each location. This is because there is no way to know how many potential victims and targets there were in each location during the 2004 and 2005 calendar years. For example, one dorm may have had more criminal violations than another simply because there were more people there, and/or because there were more suitable targets there. We did contact the university's Department of Housing and Residential Life and learned 
that the average number of occupants in each dorm is 267 students, with very little variation in this number across the 19 living centers. Only 5 dorms had substantially less than the number of average students in residence (these dorms housed 109, 128, 172,215 , and 221 students) and only one dorm had substantially more (371 students). We discuss the implications of these numbers in the findings section. It was impossible to calculate crime rates based on the number of number of students living in each dorm, since this is not a suitable indicator of the number of potential victims and offenders in any given location.

Data included crimes known to the police on campus, on non-campus buildings or property, on public property, and in on campus residential facilities. Non-campus buildings are outside town limits and thus were not considered. Public property includes roads, thoroughfares, streets, sidewalks and parking facilities. Those that are off campus were also not considered. Thus we only examined crime statistics on campus, in on campus residential facilities, and in public property located on campus.

\section{FINDINGS AND INTERPRETATIONS Most Common Crimes on Campus}

The most common crimes according to the police data in the two-year period of study (2004-2005) were theft, alcohol violations, drug violations, and vandalism. Table 1 shows the numbers of recorded offenses for each type of crime in 2004-2005.

These top four crimes on campus in 2004-2005 are similar to those from previous studies conducted on the same campus from 1997-2000. For example, findings from victimization surveys of space users on the same campus suggested that the most common crimes on campus were crimes involving legal and illegal drugs. Further, the most common self-reported form of criminal victimization on campus was 
having been offered some illegal drug while on campus. This was followed by burglary, theft, and threats of violence (Robinson and Mullen, 2001).

Police data also show that there were almost no violent crimes reported to the police for the past two years. In 2004 and 2005, there were no murders or robberies, only five sexual assaults, and 28 reported assaults (two students were murdered in 2005 but both were murdered off campus, as noted above). This, too, is nearly identical to the findings of the victimization surveys from previous years.

It should be pointed out that while the police crime data have consistently revealed less than ten sexual assaults per year on campus per (and typically less than five), two previous victimization studies conducted on campus estimated the number of sexual assaults to be far higher (Mullen, Robinson, and Paulsen, 2001; Robinson and Mullen, 2001). Thus, consistent with any town or city - and heightened by the fact that there is also a town Police Department that may take criminal complaints related to sexual assaults - the number of calls for service for the crime of sexual assault is likely a vast underestimate (Abbey et al., 2001). It is likely that many other crimes also go unreported, including some assaults, much theft and vandalism, and probably the vast majority of alcohol and illicit drug use.

\section{Hot Spots of Crime on Campus}

With these additional limitations in mind, we plotted crimes known to the police on campus maps to visually demonstrate which areas of campus were most likely to host criminal activity. Figures 1 through 6 shows the campus crime maps.

In looking at the spatial distribution of crimes known to the police on campus, some important findings are evident. First, crime locations for illicit drug violations, alcohol violations, breaking and entering, assault, communicating threats, harassment, 
sexual assault, forcible fondling, vandalism, and theft are all concentrated largely at or near student dormitories. This finding is not unexpected as most student activity is centered around dormitories and thus victimization would also be expected to center around these dorms, consistent with routine activity theory and crime pattern theory (Brantingham and Brantingham, 1993; Cohen and Felson, 1979; Eck and Weisburd, 1995; Felson, 2002; Rossmo, 2000).

Previous studies of student lifestyles show that student spend most of their time at or near their residences (Robinson, 1999a). Thus, it is generally at student dorms their main nodes of activity - where most opportunities for crime exist. All university dorms can be considered crime generators because there large numbers of students congregate there for reasons unrelated to criminal behavior (and sometimes for reasons related to criminal behavior).

Second, high traffic areas between main parts of campus, such as near educational buildings and parking areas near pedestrian tunnels, also experience a moderate amount of crime, including thefts, vandalism, and crimes against automobiles (e.g., hit and run, property damage). This is also consistent with routine activity theory and crime mapping theory, as there are higher opportunities for crimes here due to the automobile and pedestrian traffic patterns at these places (Brantingham and Brantingham, 1993; Cohen and Felson, 1979; Eck and Weisburd, 1995; Felson, 2002; Rossmo, 2000). Essentially, it is reasonable to expect that the paths students and other campus space users travel to and from their regular nodes of activities will host higher amounts of crime.

Third, there are three major places where crime clusters on campus for the crimes of illicit drug violations (Figure 1), alcohol violations (Figure 2), breaking and entering (Figure 3), and assault, communicating threats, harassment, sexual assault, \& 
forcible fondling (Figure 4). The crimes of assault, communicating threats, harassment, sexual assault, and forcible fondling were grouped together because of the infrequent nature of each crime on campus and the similar nature of those crimes. That is, each is a crime that rarely occurs on campus and typically involves violence that is related to relationships between students (Carlson, 2005; Gover, 2004; Griffing et al., 2005; Lauritsen and Schaum, 2004; Thompson and Kingree, 2006).

The three places where these various crimes cluster can be considered the main "hot spots" of crime on the campus. Another crime that tended to cluster in these same places, but far less frequency, was disorderly conduct.

These three areas are dorms located around potential crime-generating environments. The first two areas are groups of dorms located across from the football stadium, its parking lots, and an open field known as "Duck Pond field." Duck Pond Field is an area that is used by students for recreational and sporting activities, including drinking alcohol associated with football games, playing sports, and hanging out, as well as some illicit drug use associated with parties. As such, these two areas can also be considered crime attractors since they will regularly draw in students looking to use and abuse alcohol and other drugs as part of social gatherings.

\section{Hot Spots of Crime on Campus: A Closer Look}

The first area (labeled Area \#1 in the figures) is the "Yosef Hollow Community," and is comprised of five dorms. One of these dorms is all male, whereas the rest are coed. One of the dorms houses the "Wellness Community," where use of drugs, alcohol, or tobacco products will result in removal from the dorm. The Wellness Community could possibly act as a social control on the behavior of those in this dorm. Interestingly, both the all male dorm and the adjacent dorm which houses the "Wellness Community" 
had a large amount of alcohol and drug violations, as well as acts of vandalism, theft, and disorderly conduct violations. None of the smaller dorms are found in this group of dorms.

The second area (labeled Area \#2 in the figures) is the "Stadium Heights Community," and is comprised of five dorms. One of these dorms is all female, whereas the rest are co-ed. Interestingly, the all female dorm had no alcohol or drug violations, and only a few acts of vandalism or theft. Similarly, the "Living Learning Center," which houses some academic "learning communities," had very few crimes known to the police, with the exception of theft which fell within a campus hot spot. The Living Learning Center could also serve as a social control on the behavior of students in the dorm. The Stadium Heights Community is a hot spot of crime, even though three of the smaller dorms on campus are located in this cluster. The rate of crimes known to the police in these smaller dorms is likely roughly equivalent to those large dorms in Area \#1.

The third area (labeled Area \#3 in the figures) is the "Eastridge Community," and is comprised of five co-ed dorms. It is located on the other side of campus, near a major thoroughfare and a university owned social club - an area that is also used by students for recreational activities, including concerts, dances, and other events where students twenty-one years and older are permitted to possess a six-pack of beer for each event (as such this can be considered a crime attractor). These dorms are closest to this club facility and to other establishments off campus where students frequently hang out for social purposes (e.g., restaurants and bars). None of the smaller dorms are found in this group of dorms.

Three other nearby dorms, part of a different community - the "Pinnacle Community" (which also includes an apartment complex located on the other side of 
campus up a mountain that houses married, single parent, graduate and non-traditional students), are also near enough the university social club to house a large number of alcohol and illicit drug violations, as well as acts of theft and vandalism. The largest dorm on campus is found in the Pinnacle community which hosts a large amount of crimes known to the police.

Yet, the one dorm in this area that houses university honors students (which is also the smallest dorm on campus), had no alcohol or illicit drug violations, no reported acts of vandalism, and only two reported thefts in a two year period. Similarly, the apartment complex that houses older and married students had very few crimes known to the police relative to other housing locations on campus (despite being of average size relative to all dorms on campus). The small number of crimes known to the police at the small honors dorm is due in part to the relative size of the dorm; yet, its lower incidence of crimes known to the police (as well as those at the apartment complex which houses older and married students) if likely due to the nature of student population there. These places serve as social controls on potential maladaptive behavior.

The crimes of assault, communicating threats, harassment, sexual assault, \& forcible fondling, most occurred in the three hot spots of crime, as well. Alcohol violations also clustered at these places, in addition to a fourth place. This fourth place (labeled Area \#4 in figure 2) is the football stadium itself, another crime attractor. Almost all the incidents here occurred on game days inside the stadium, and thus this hot spot is situational rather than static.

Theft was most prevalent in the above four areas, but also occurred frequently at a few others places. Given the widespread nature of theft on campus, it was impossible to neatly identify hot spots and thus none are indicated in Figure 6. The location of theft on campus is the most unique, primarily because it appears to occur occasionally all 
across campus. The same can be said for vandalism on campus, which is why no hot spots of vandalism are indicated in Figure 5. The dispersal of theft and vandalism across the campus likely reflects the numerous opportunities that are present across university buildings.

The primary difference between the location of theft and vandalism from other crimes on campus is that they tend to occur more frequently in academic buildings on campus (e.g., classroom buildings) and student support buildings (e.g., student union), as well as at some athletic facilities (e.g., university gym). These are places where opportunities for crime abound and where guardianship is lower (especially at night) than in student residences. Alcohol and illicit drug violations tend to occur almost exclusively at and around certain dorms and the football stadium. Part of this owes itself to opportunity factors - students spend more time in their dorms and socializing at certain places than they do in class, and alcohol and illicit drug use are obviously more accepted at these places than in academic buildings on campus (Robinson, 1999a). Other findings

We found some additional outcomes that are of interest to our study of campus hot spots. First, not all student dormitories were characterized by a high level of crime, as newer student dormitories built farther from the center of campus experienced less reported criminal activity. The relative lack of criminal activity at these newer dormitories is probably due to both their distance from the center of campus, making them both socially and physically isolated from the center of campus. Crime pattern theorists would say these dorms are out of the awareness space of most campus users, and are thus less prone to victimization.

Second, the crime of DWI almost universally occurred on one street. The street is a main thoroughfare through campus (the primary path used by students driving cars) 
that connects nearly every dorm with restaurants, bars, and other student-centered locations. It is safe to say that this street stands out as a DWI hot spot because it is the only main thoroughfare through campus and thus is the main area where police officers will look for intoxicated drivers.

Third, there is a high degree of consistency between findings from the previous studies of student fear of specific campus areas, perceptions of students of where crime occurs, and the location of reported crime on campus in the current study. In general, areas identified by students in the previous studies as where they were afraid to go because of criminal victimization are consistent with areas where reported crime is highest on campus, although campus tunnels under streets (a place where some students feared going) host literally no reported criminal activity, except the occasional act of vandalism (Mullen, Robinson, and Paulsen, 2001; Robinson and Mullen, 2001).

In the earlier studies, $88 \%$ of students surveyed felt that most crime occurred in dorms and parking lots, areas where the spatial analysis of reported crime shows have high concentrations of crime (Mullen, Robinson, and Paulsen, 2001; Robinson and Mullen, 2001). On the campus of study, students have an accurate understanding of where street crimes occur, at least based on police data.

Hot spots of crime on campus: Potential explanations

As for the hot spots on campus, it is not clear whether they occur because of enduring characteristics about targets which make them attractive or suitable to multiple offenders (the risk heterogeneity argument), or if they occur because of factors related to the initial victimization (the state-dependent argument). Is it because some people and places are different in some way that attracts offenders or is it because initial victimizations result in the reinforcement of offenders' criminal behaviors? (Everson, 2003; Farell, Philipps and Pease, 1995; Robinson, 1998b). 
In the case of the campus, it is likely that the answer to each of these questions is yes. That is, it is likely that some places on campus are hot spots of crime because of factors related to criminal opportunities and student lifestyles that are consistently present, meaning criminality will likely occur there consistently over time. These are probably crime generators. Some of these places might also be more likely to host criminality due to a "legend" or "reputation" as the "party dorm" or a "cool hang-out," regardless of who lives there. These are better understood as crime attractors. Clearly, a handful of dorms on campus, including the largest dorm, the all male dorm, and the dorms that border the football stadium and the social club, have the largest number of crimes known to the police. Appropriately, these are also the dorms on campus that are known to be the "party dorms."

Applying community level factors that explain why some neighborhoods have higher crime rates than others to the issue of hot spots may also provide some explanation as to why some areas of a university campus have higher occurrences of crimes than others. Such factors include:

- Community composition (with higher rates of some types of people living in a community, crime rates are found to be higher);

- Community social structure (crime rates are also affected by the way in which inhabitants of an area interact);

- Oppositional culture (high crime neighborhoods are thought to be characterized by an "oppositional culture" or subcultural values that stem from frustration arising out of financial strains); 
- Criminogenic commodities (rates of youth violence tend to be associated with the presence of places where alcohol use, drug use, and gun ownership are prevalent); and

- Social and physical disorder (high crime rate areas tend to be characterized by incivilities, which are signs that a neighborhood is in disarray) (Paulsen and Robinson, 2004; Sherman et al., 1998).

Social and physical disorder is not problematic anywhere on campus. Again, the campus is highly attractive and rated as aesthetically pleasing by space uses. Further, there is no evidence that some places on campus are characterized by different levels of oppositional cultures, although this is possible (some dorms may attract different types of people than others). Again, the all male dorm tends to have a higher level of crimes known to the police than many other dorms. Community composition factors may explain higher crimes known to the police on some areas of campus, as may community social structure factors. That is, some dorms on campus, for whatever reason, have a more pronounced reputation for partying behaviors.

Criminogenic commodities may very well vary by campus location, as alcohol, illicit drugs, and weapons possession may simply be higher in some locations than others based on who lives there. As noted earlier, part of this owes itself to the proximity of dorms to criminogenic locations such as the football stadium and university operated social club. 


\section{IMPLICATIONS FOR CRIME PREVENTION}

The findings of this study - based on crimes known to the police - show that there are some unique areas on campus that are most crime prone. Specifically, there are a few groups of dorms that generate the most known offenses for larceny, vandalism, breaking and entering, alcohol and illicit drug violations, assault, communicating threats, harassment, sexual assault, \& forcible fondling, as well as disorderly conduct.

Interestingly, the places on campus indicated by 2004 and 2005 police data as the most crime-prone - the three main hot spots on campus - are the same places found to generate the most fear and perception of crime risk by previous studies of the university campus that utilized victimization surveys of students, faculty, and staff. If this means, as we think it does, that the location of criminality on campus is relatively stable, this offers some unique opportunities for prevention strategies aimed at breaking the cycle of crime in some locations on campus. That the place of crime has remained stable from 1997 to 2006 is important, especially considering that new students have come to campus and that the campus has been significantly developed (i.e., built up).

The crime of sexual assault, which is likely vastly underreported on campus, is not spatially clustered due to any particular environmental conditions, and it is likely that it occurs in the same locations that alcohol use and illicit drug use is most prevalent. Sexual assault and alcohol use are clearly linked (Abbey, 2002; Abbey et al, 2001; Fisher et al, 1998; Testa and Livingston, 1999; Robinson, 2004; Wecshler et al, 1995; Wechsler and Wuethrich, 2003). That the crimes of assault, communicating threats, harassment, sexual assault, \& forcible fondling all occur with the greatest frequency in places where alcohol use is most widespread should lead to preventive action in these dorms. 
The most significant problem on the campus appears to be alcohol and illicit drug use. Since it appears that the same places that generate these offenses also generate the most incidents of other types of crimes, it is logical that alcohol and illicit drug use are driving these other criminal events, especially considering the student lifestyle (Robinson, 1999a). Young people often commit acts of stupidity - including disorderly conduct, vandalism, theft, assault, communicating threats, harassment, and more seriously, sexual assault - under the influence of drugs, especially alcohol (Robinson, 2004).

Alcohol is the one drug that would most likely lead to a psychopharmacological effect on criminality (Robinson and Scherlen, 2007). Because of the effects of the drug on the brain, as well as because of how it is consumed by young people and the setting in which it is consumed - alcohol is the one drug that is most likely responsible for the clustering of criminality at particular locations on campus. This warrants serious investigation into the effects that alcohol consumption has on criminality on this particular campus. Further, it warrants dedicated action on the part of the university administration to combat irresponsible alcohol use - especially by underage students on the campus. This is not meant to de-emphasize the issue of illicit drug use on campus, which is the one crime that is likely most prevalent based on previous student surveys. Further, it is the illicit drug market that led to the murders of two students just more than one year apart.

Yet, even the Office of National Drug Control Policy has noted that when it comes to drugs and crime \& mayhem, alcohol leads the pack (Robinson and Scherlen, 2007). At the university of study, there is no evidence showing that students drink more alcohol than on other campuses, or that they drink any differently. Still, this is the one drug that is most responsible for antisocial behavior and alcohol use clearly plays a 
meaningful role in the lives of a sizable portion of the student body throughout the year. Thus, one logical crime prevention strategy would be alcohol awareness campaigns directed at all students, and especially those that live in the particular dorms that comprise the hot spots of crime on campus.

Finally, other crime prevention strategies should be developed and implemented at the hot spots of crime on campus. Given that displacement is not likely to result, and that there is likely to be a diffusion of benefits, it makes very good sense to focus efforts on the areas that are most likely to host alcohol and illicit drug violations, theft, and vandalism (Clarke, 1998; Clarke and Weisburd, 1994; Cohen and Tita, 1999; Paulsen and Robinson, 2004). This would include the many well-tested efforts aimed at CPTED and situational crime prevention.

The strategies that would most likely be successful to reduce these crimes vary by type of crime. For example, a large number of thefts could be prevented by increasing student awareness of problem areas (e.g., the library, the gym) and encouraging students to maintain guardianship of their property at all times. A large amount of vandalism could be prevented by better securing construction sites on campus and increasing surveillability of other locations at night. And as noted above, much alcohol and illicit drug violations could be prevented by educating students about the dangers of irresponsible use and abuse, as well as giving students more opportunities for alternative forms of entertainment. Given the relationships between alcohol \& illicit drug use and criminality, reducing alcohol and illicit drug use would likely reduce some thefts, acts of vandalism, disorderly conduct, assaults, communication of threats, acts of harassment, sexual assault, and probably breaking \& entering. 


\section{REFERENCES}

Abbey, A. (2002). Alcohol-related sexual assault: A common problem among college students. Journal of Studies on Alcohol, Supplement 14, 118-128.

Abbey, A., Zawacki, T., Buck, P. Clinton, A., \& McAuslan, P. (2001). Alcohol and sexual assault. Alcohol Health and Research World, 25(1). Retrieved June 3, 2006, from http://www.athealth.com/Practitioner/ceduc/alc assault.html

Astor, R., Meyer, H, \& Behre, W. (1999). Unowned places and times: Maps and interviews about violence in high schools. American Educational Research Journal, 36(1), 3-42.

Block, C., \& Block, R. (1995). Street gang crime in Chicago. Research in Brief. Washington, DC: United States Department of Justice. National Institute of Justice.

Block, C., \& Block, R. (1998). Homicides in Chicago, 1965-1995 [Computer file]. 4th ICPSR version. Chicago, IL: Illinois Criminal Justice Information Authority. Ann Arbor, MI: Inter-university Consortium for Political and Social Research.

Block, C., \& Christakos, A. (1995). Major trends in Chicago homicide: 1965-1994. Research in Brief. Washington, DC: United States Department of Justice. National Institute of Justice.

Bohm, R. (2000). A primer on crime and delinquency theory. Belmont, CA: Wadsworth.

Brantingham, P., \& P. Brantingham (1993). Environment, routine, and situation: Toward a pattern theory of crime. In R. Clarke \& M. Felson (Eds.), Routine activity and rational choice. Advances in criminological theory 5. New Brunswick, NJ: Transaction Publishers.

Brantingham, P, \& Brantingham, P. (1994). Surveying campus crime: What can be done

to reduce crime and fear? Security Journal, 5(3), 160-171.

Brantingham, P., \& Brantingham, P. (1999). A theoretical model of crime hot spot generation. Studies on Crime and Crime Prevention, 8(1), 7-26.

Brantingham, P., \& Faust, F. (1976). A conceptual model of crime prevention. Crime \& Delinquency, 7, 284-295.

Brinkley Jr, W., \& Laster, D. (2003). Campus crime in Missouri: An analysis and comparison of crime in four-year colleges and universities. Journal of Security Administration, 26(1), 1-15.

Bromley, M. (1994). Correlates of campus crime: A nationwide exploratory study of large universities. Journal of Security Administration, 17(1), 37-52. 
Carlson, B. (2005). The most important things learned about violence and trauma in the past 20 years. Journal of Interpersonal Violence, 20(1), 119-126.

Clarke, R. (1992). Situational crime prevention: Successful case studies. Albany, NY: Harrow and Hest.

Clarke, R. (1998). The theory and practice of situational crime prevention. Retrieved June 5, 2006, from http://www.edoca.net/Resources/Articles/Clarke the theory and practice of sit uational crime prevention.pdf

Clarke, R., \& Weisburd, D. (1994). Diffusion of crime control benefits: Observations of the reverse of displacement. Crime Prevention Studies, 2, 165-184.

Clarke, R. (2001). Rational choice. In R. Paternoster\& R. Bachman (Eds.), Explaining crime and criminals. Los Angeles, CA: Roxbury.

Clarke, R., \& Eck, J. (2006). Crime analysis for problem solvers in 60 steps. Center for Problem Oriented Policing. Retrieved June 5, 2006, from http://www.popcenter.org/learning/60steps/index.cfm?stepNum=17.

Cochran, J., \& Bromley, M. (2002). Auto burglaries in an entertainment district: Patron perceptions of risks and precautionary behaviors. Journal of Security Administration, 25(1), 1.

Cochran, J., Bromley, M., \& Branch, K. (2000). Victimization and fear of crime in an entertainment district crime "hot spot": A test of structural-choice theory. American Journal of Criminal Justice, 24(2), 189-201.

Cohen, J., \& Tita, G. (1999). Diffusion in homicide: Exploring a general method for detecting spatial diffusion processes. Journal of Quantitative Criminology, 15(4), 451-493.

Cohen, L., \& Felson, M. (1979). Social change and crime rate trends: A routine activity approach. American Sociological Review, 44, 588-608.

Cornish, D., \& Clarke, R (Eds.) (1986). The reasoning criminal: Rational choice perspectives on offending. New York, NY: Springer-Verlag.

Crowe, T. (1991). Crime prevention through environmental design: Applications of architectural design and space management concepts. Boston, MA: ButterworthHeinemann.

Eck, J., \& Weisburd, D. (1995). Crime places in crime theory. In J. Eck \& D. Weisburd (Eds.), Crime prevention studies: Crime and place. Monsey, NY: Willow Tree Press.

Everson, S. (2003). Repeat victimization and "prolific" offending: Chance or choice? International Journal of Police Science \& Management, 5(3), 180-194. 
Farrell, G., Phillips, C., \& Pease, K. (1995). Like taking candy: why does repeat victimization occur? British Journal of Criminology, 35(3), 384-399.

Felson, M. (2002). Crime and everyday life ( $3^{\text {rd }}$ Ed.). Beverly Hills, CA: Sage.

Fisher, B., \& Sloan III, J. (1993). University response to the Campus Security Act of 1990: Evaluating programs designed to reduce campus crime. Journal of Security Administration, 16(1), 67-80.

Fisher, B., Sloan, J., Cullen, F., \& Lu, C. (1998). Crime in the ivory tower: The level and sources of student victimization. Criminology, 36(3), 671-710.

Fisher, B., \& Wilkes, A (2003). A tale of two ivory towers: A comparative analysis of victimization rates and risks between university students in the United States and England. British Journal of Criminology, 43(3), 526-545.

Fox, J., \& Hellman, D. (1985). Location and other correlates of campus crime. Journal of Criminal Justice, 13(5), 429-444.

Gover, A. (2004). Risky lifestyles and dating violence: A theoretical test of violent victimization. Journal of Criminal Justice, 32(2), 171-180.

Green, L. (1995). Cleaning up drug hot spots in Oakland, California: The displacement and diffusion effects. Justice Quarterly, 12, 737-754.

Griffing, S., Ragin, D., Morrison, S., Sage, R., Madry, L., \& Primm, B. (2005). Reasons for returning to abusive relationships: Effects of prior victimization. Journal of Family Violence, 20(5), 341-348.

Henson, V., \& Stone, W. (1999). Campus crime: A victimization study. Journal of Criminal Justice, 27(4), 295-307.

Johnson, I., \& Sigler, R. (1996). Forced sexual intercourse on campus: Crime or offensive behavior? Journal of Contemporary Criminal Justice, 12(1), 54-68.

Koper, C. (1995). Just enough police presence: Reducing crime and disorderly behavior by optimizing patrol time in crime hot spots. Justice Quarterly, 12(4), 649-672.

Lauritsen, J., \& Schaum, R. (2004). The social ecology of violence against women. Criminology, 42(2), 323-357.

Loukaitou-Sideris, A. (1999). Hot spots of bus stop crime: The importance of environmental attributes. Journal of the American Planning Association, 65(4), 83-95.

Moriarty, L., \& Pelfrey, W. (1996). Exploring explanations for campus crime: Examining internal and external factors. Journal of Contemporary Criminal Justice, 12(1), 108-120. 
Mullen, K., Robinson, M., \& Paulsen, D. (2001). Crime on campus: Repeat criminal victimization and hot spots of crime. Paper presented to the annual meeting of the American Society of Criminology, November.

Mustaine, E., \& Tewksbury, R. (1998). Predicting risks of larceny theft victimization: A routine activity analysis using refined lifestyle measures. Criminology, 36(4), 829-857.

O'Kane, J. Fisher, R., \& Green, L. (1994). Mapping campus crime. Security Journal, 5(3), 172-179.

Paulsen, D., \& Robinson, M. (2004). Spatial aspects of crime: Theory and practice. Boston, MA: Allyn \& Bacon.

Rengert, G., \& Lowell, R. (2005). Combating campus crime with mapping and analysis. Crime Mapping News, 7(1), 1-5.

Rengert, G., Mattson, M., \& Henderson, K. (2001). Campus security: Situational crime prevention in high-density environments. Cullompton, Devon, UK: Criminal Justice Press.

Richards, G. (1996). The security survey: Creating a proactive foundation for campus crime prevention. Journal of Contemporary Criminal Justice, 12(1), 45-53.

Robinson, M. (1998a). Accessible targets, but not advisable ones: The role of "accessibility" in student apartment burglary. Journal of Security Administration, 21(1), 29-43.

Robinson, M. (1998b). The time period of heightened risk for repeat burglary victimization. British Journal of Criminology, 38(1), 76-85.

Robinson, M. (1999a). Lifestyles, routine activities, and residential burglary victimization. Journal of Crime and Justice, 22(1), 27-56.

Robinson, M. (1999b). The theoretical development of crime prevention through environmental design (CPTED). Advances in Criminological Theory, 8, 427-462.

Robinson, M. (2004). Why crime? An integrated systems theory of antisocial behavior. Upper Saddle River, NJ: Prentice-Hall.

Robinson, M. (2005). Justice blind? Ideals and realities of American criminal justice $\left(2^{\text {nd }}\right.$ Edition). Upper Saddle River, NJ: Prentice Hall.

Robinson, M, \& Mullen, K. (2001). Crime on campus: A survey of space users. Crime prevention and community safety: An international journal, 3(4), 33-46.

Robinson, M., \& Scherlen, R. (2007). Lies, damned lies, and drug war statistics. SUNY, NY: SUNY Press. 
Roncek, D., \& Maier, P. (1991). Bars, blocks, and crimes revisited: Linking the theory of routine activities to the empiricism of "hot spots." Criminology, 29(4), 725753.

Rossmo, K. (2000). Geographic profiling. Boca Raton, FL: CRC Press.

Schwartz, M., DeKeseredy, W., Tait, D., \& Alvi, S. (2001). Male peer support and a feminist routine activities theory: Understanding sexual assault on the college campus. Justice Quarterly, 18(3), 623-649.

Sherman, L., Gartin, P., \& Buerger, M. (1989). Hot spots of predatory crime: Routine activities and the criminology of place. Criminology, 27(1), 27-55.

Sherman, L., Gottfredson, D., MacKenzie, D., Eck, J., Reuter, P., \& Bushway, S. (1998). Preventing crime: What works, what doesn't, what's promising. NIJ Research in Brief July. Retrieved June 5, 2006, from www.ncjrs.org/pdffiles/171676.pdf

Sherman, L., \& Rogan, L. (1995). Deterrent effects of police raids on crack houses: A randomized, controlled experiment. Justice Quarterly, 12(4), 755-781.

Sherman, L., \& Weisburd, D. (1995). General deterrent effects of police patrol in crime "hot spots": A randomized, controlled trial. Justice Quarterly, 12(4), 625-648.

Siegel, D., \& Raymond, C. (1992). An ecological approach to violent campus crime. Journal of Security Administration, 15(2), 19-29.

Sloan III, J. (1992). Campus crime and campus communities: An analysis of crimes known to campus police and security. Journal of Security Administration, 15(2), $31-47$.

Sloan III, J. (1994). The correlates of campus crime: An analysis of reported crimes on college and university campuses. Journal of Criminal Justice, 22(1), 51.

Sloan III, J., Fisher, B., \& Cullen, F. (1997). Assessing the Student Right-to-Know and Campus Security Act of 1990: An analysis of the victim reporting practices of college and university students. Crime and Delinquency, 43(2), 148-168.

Stitt, B., Nichols, M., \& Giacopassi, D. (2003). Does the presence of casinos increase crime? An examination of casino and control communities. Crime and Delinquency, 49(2), 253-284.

Testa, M., \& Livingston, J. (1999). Qualitative analysis of women's experiences of sexual aggression: Focus on the role of alcohol. Psychology of Women

Quarterly, 23, 573-589. 
Tewksbury, R. \& Mustaine, E. (2003). College students' lifestyles and self-protective behaviors: Further considerations of the guardianship concept in routine activity theory. Criminal Justice and Behavior, 30(3), 302-327.University (2006), Annual Crime Report.

Thompson, M., \& Kingree, J. (2006). The roles of victim and perpetrator alcohol use in intimate partner violence outcomes. Journal of Interpersonal Violence, 21(2), 163-177.

Volkwein, J., Szelest, B., \& Lizotte, A. (1995). The relationship of campus crime to campus and student characteristics. Research in Higher Education, 36(6), 64770.

Warr M. (1990). Dangerous situations: Social context and fear of victimization. Social Forces, 68(3), 891-907.

Wechsler H, Dowdall G., Davenport A., \& Castillo, S. (1995). Correlates of college student binge drinking. American Journal of Public Health, 85, 982-985.

Wechsler H. \& Wuethrich, B. (2003). Dying to drink : Confronting binge drinking on college campuses New York: Rodale Books.

Weisburd, D., Bushway, S., Lum, C., \& Yang, S. (2004). Trajectories of crime at places: A longitudinal study of street segments in the city of Seattle. Criminology, 42(2), 283-321.

Weisburd, D., \& Green, L. (1995). Policing drug hot spots: The Jersey City drug market analysis experiment. Justice Quarterly, 12(4), 711-735.

Wooldredge, J., Cullen, F., \& Latessa, E. (1995). Predicting the likelihood of faculty victimization: Individual demographics and routine activities. In J. Sloan III \& B. Fisher (Eds)., Campus crime: Legal, social, and policy context. Springfield, IL: Charles Thomas Publisher. 
TABLE 1

CRIMES KNOWN TO THE POLICE (2004-2005)

$\begin{array}{lrrr}\text { Type of Offense } & 2004 & 2005 & \text { Total } \\ \text { Alcohol Violations } & 163 & 221 & 384 \\ \text { Arson } & 4 & 2 & 6 \\ \text { Assault } & 13 & 15 & 28 \\ \text { Breaking \& Entering } & 17 & 13 & 30 \\ \text { Child Neglect } & 1 & 0 & 1 \\ \text { Communicating Threats } & 14 & 12 & 26 \\ \text { Disorderly Conduct } & 20 & 30 & 50 \\ \text { Domestic Dispute } & 0 & 6 & 6 \\ \text { DWI } & 31 & 29 & 60 \\ \text { Forcible Fondling } & 2 & 0 & 2 \\ \text { Forgery } & 1 & 1 & 2 \\ \text { Fraud } & 6 & 5 & 11 \\ \text { Hacking } & 1 & 0 & 1 \\ \text { Harassment } & 12 & 21 & 33 \\ \text { Harassing Phone Calls } & 17 & 17 & 34 \\ \text { Hit and Run } & 14 & 22 & 36 \\ \text { Illicit Drug Violations } & 116 & 139 & 255 \\ \text { Inappropriate Behavior } & 2 & 1 & 3 \\ \text { Indecent Exposure } & 1 & 0 & 1 \\ \text { Motor Vehicle Theft } & 7 & 3 & 10 \\ \text { Peeper } & 0 & 1 & 1 \\ \text { Possessing Stolen Property } & 3 & 3 & 6 \\ \text { Property Damage } & 15 & 10 & 25 \\ \text { Sexual Assault } & 3 & 2 & 5 \\ \text { Solicitation } & 5 & 2 & 7 \\ \text { Soliciting Sex } & 0 & 1 & 1 \\ \text { Theft } & 159 & 148 & 307 \\ \text { Trespassing } & 9 & 13 & 22 \\ \text { Vandalism } & 101 & 145 & 246 \\ \text { Weapons } & 10 & 14 & 24\end{array}$




\section{FIGURE 1}

HOT SPOTS OF DRUG VIOLATIONS KNOWN TO THE POLICE, 2004-2005

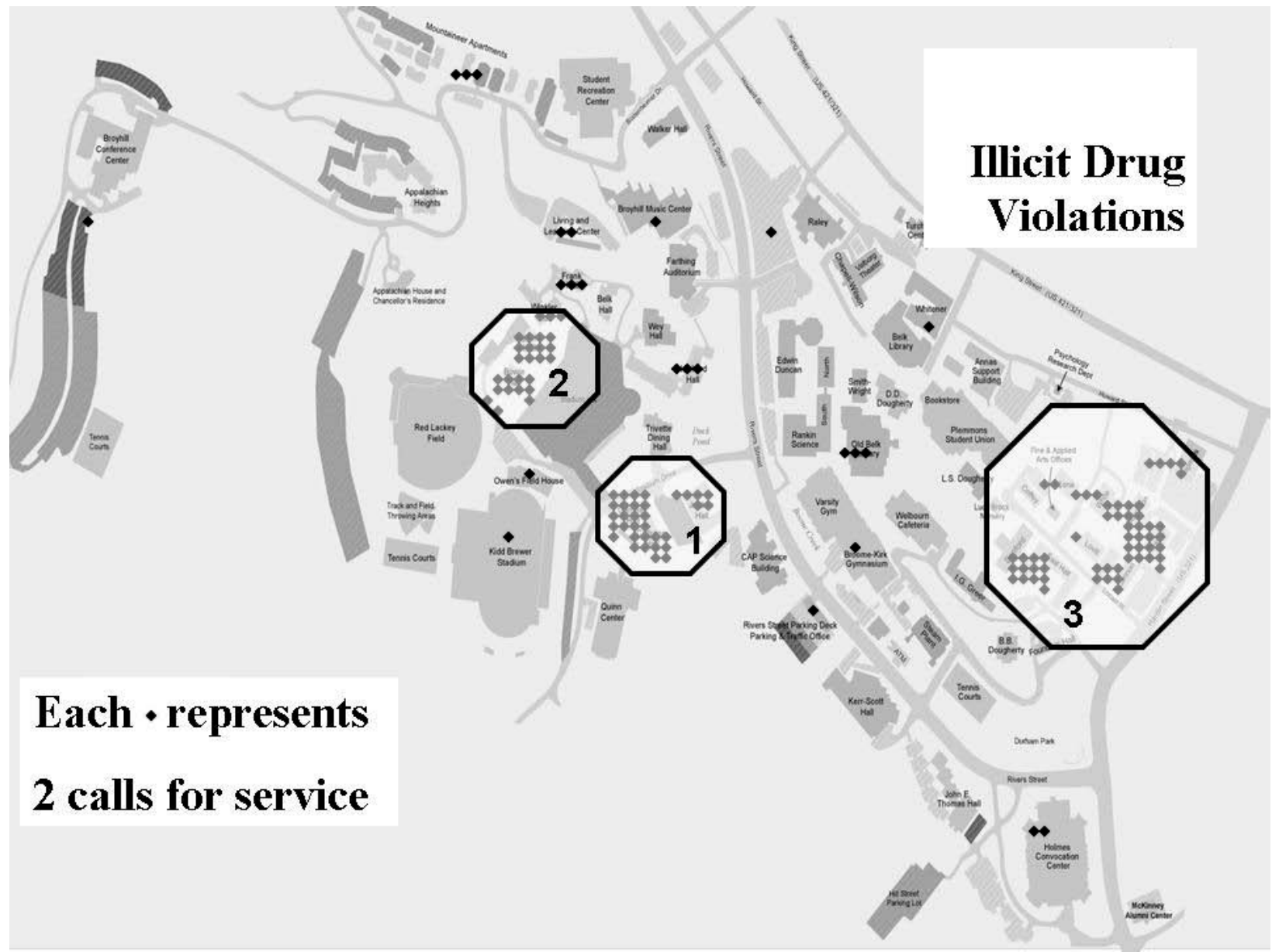


FIGURE 2

HOT SPOTS OF ALCOHOL VIOLATIONS KNOWN TO THE POLICE, 2004-2005

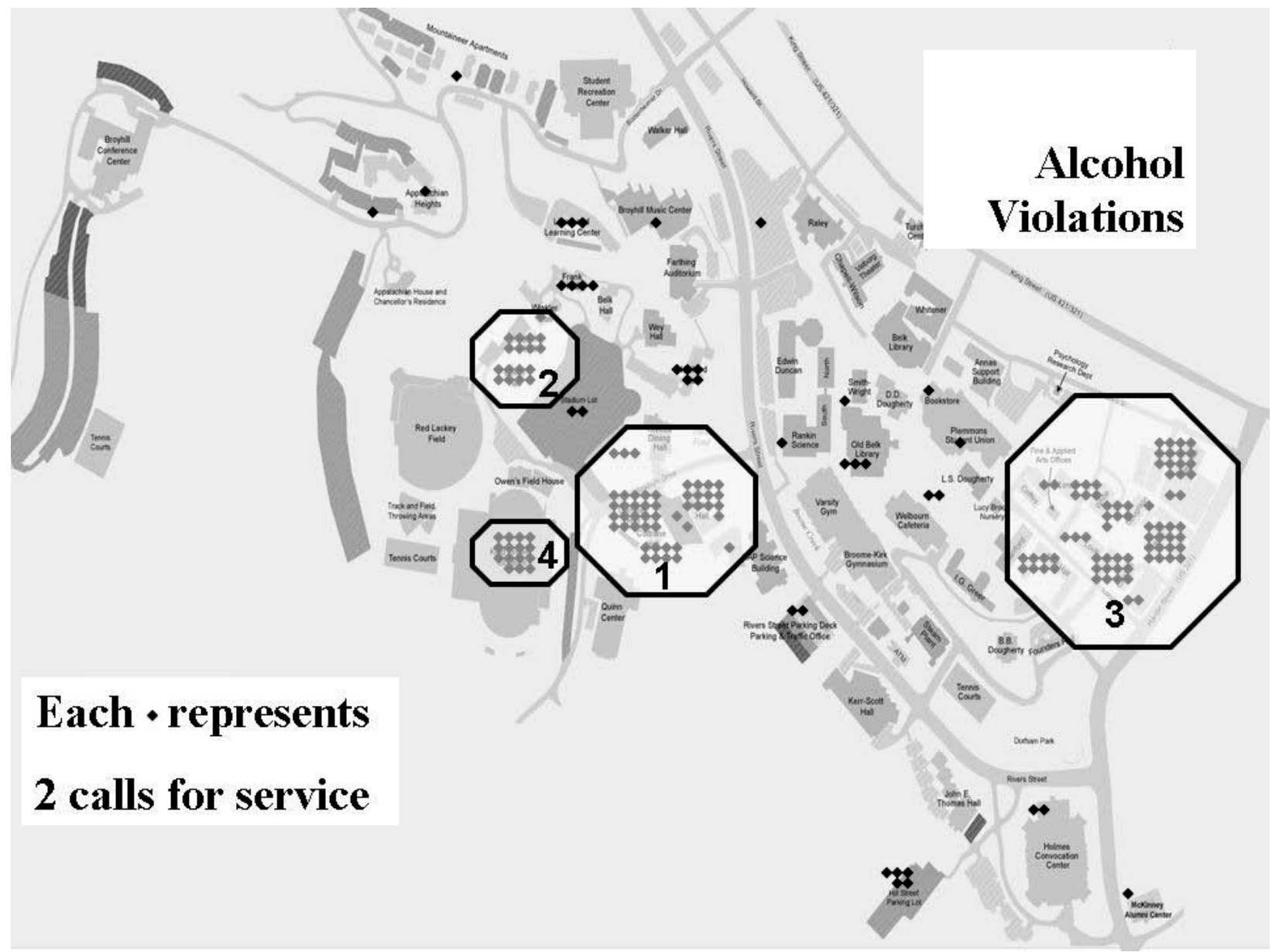


FIGURE 3

HOT SPOTS OF BREAKING \& ENTERING KNOWN TO THE POLICE, 2004-2005

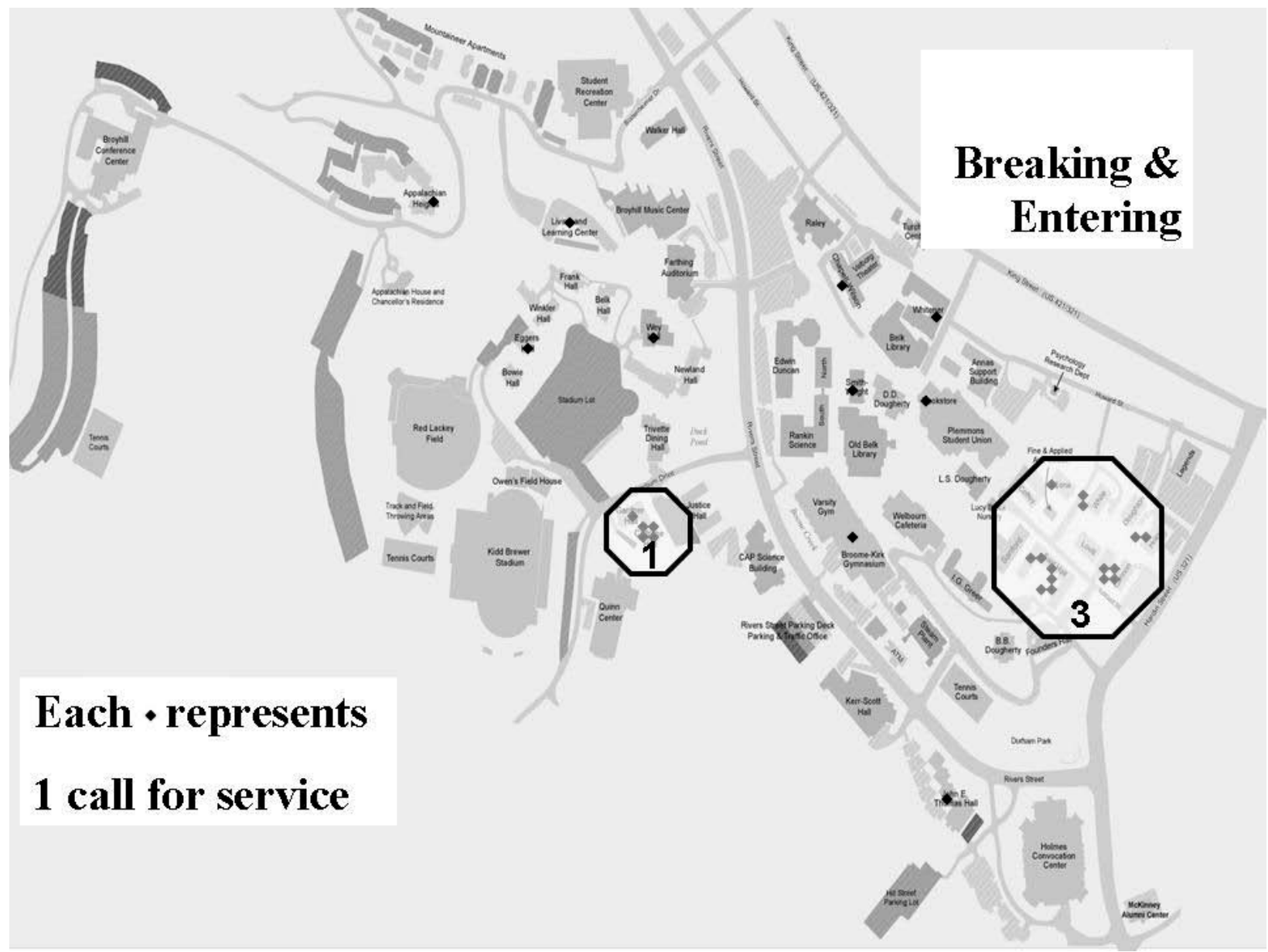


FIGURE 4

HOT SPOTS OF CRIMES THAT OFTEN OCCUR IN RELATIONSHIPS KNOWN TO THE POLICE, 2004-2005

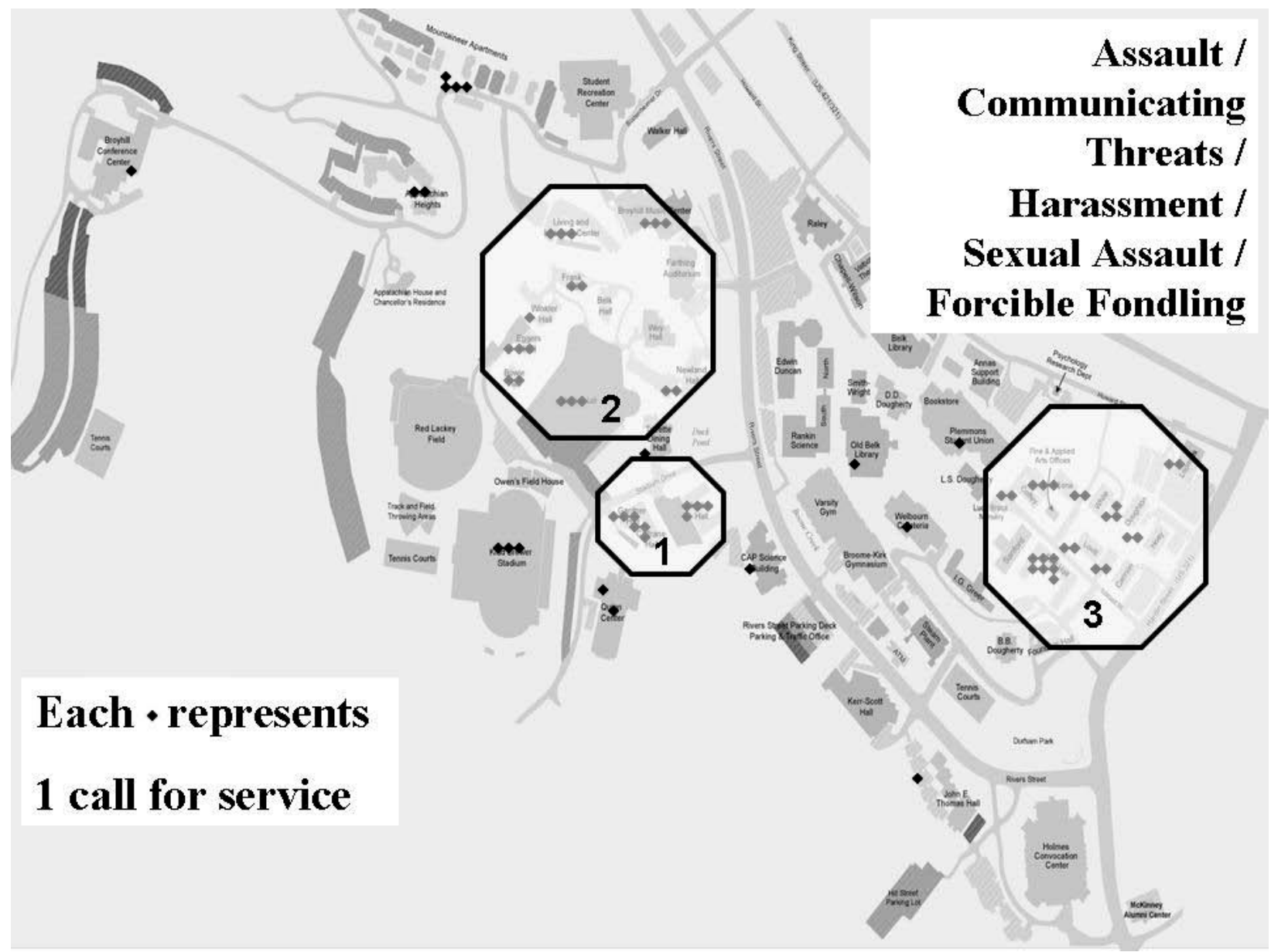




\section{FIGURE 5}

ACTS OF VANDALISM KNOWN TO THE POLICE, 2004-2005

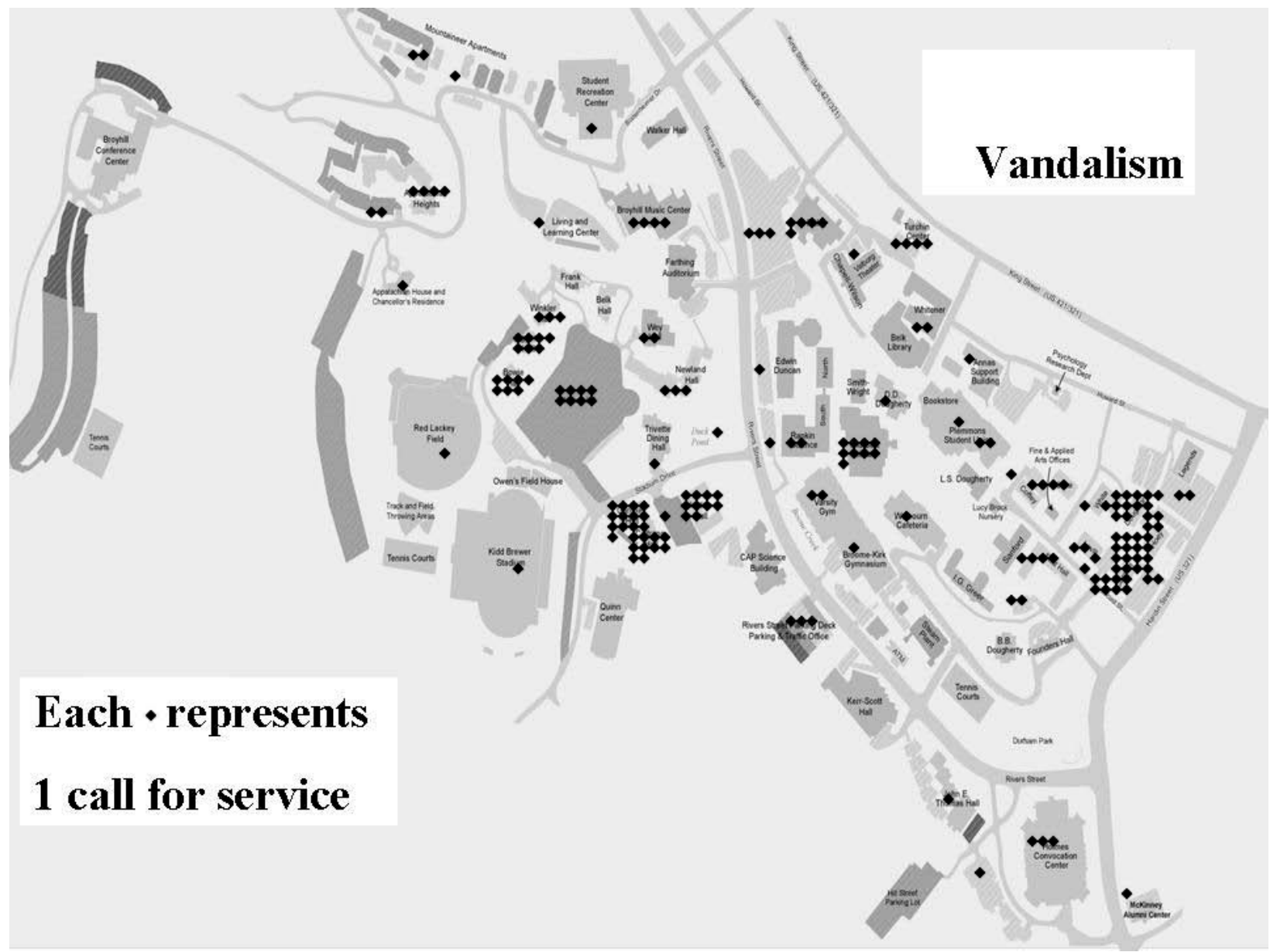


FIGURE 6

THEFTS KNOWN TO THE POLICE, 2004-2005

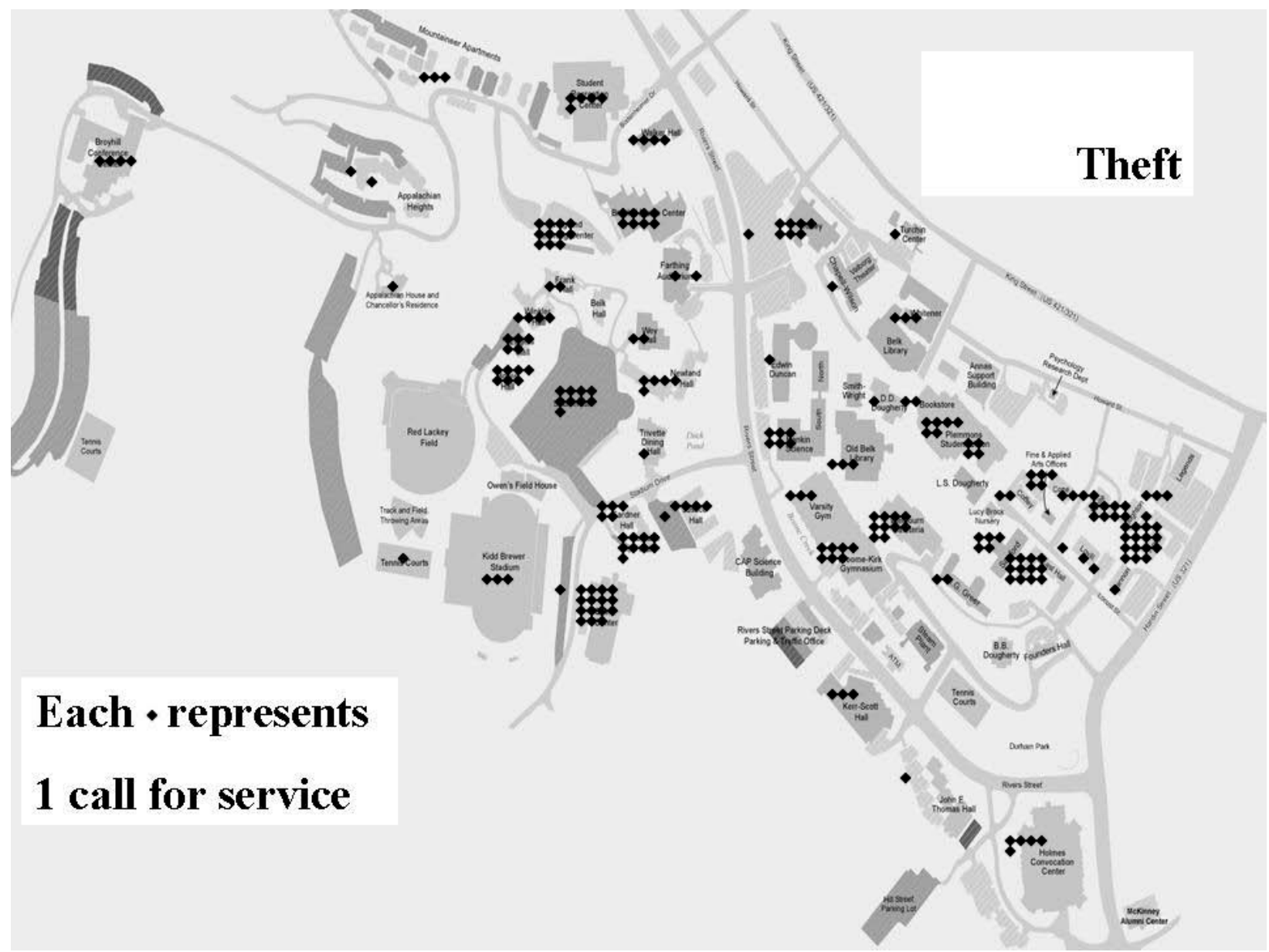




\section{BIOGRAPHICAL SKETCH}

Matthew Robinson is Associate Professor of Criminal Justice at Appalachian State University. His main areas of interest include criminological theory, crime prevention, the death penalty, the war on drugs, and injustices of the criminal justice system. He is author of Justice Blind? Ideals and Realities of American Criminal Justice (Prentice Hall, 2005), Why Crime? An Integrated Systems Theory of Antisocial Behavior (Prentice Hall, 2004), and co-author of Spatial Aspects of Crime: Theory and Practice (Allyn \& Bacon, 2004). Robinson's forthcoming books include Lies, Damned Lies, and Statistics: A Critical Analysis of Claims Made by the Office of National Drug Control Policy (SUNY Press, 2007) and Death Nation: The Experts Explain American Capital Punishment (Prentice-Hall, 2007). He is also Past President of the Southern Criminal Justice Association.

Sunghoon Roh is Assistant Professor of Criminal Justice at Appalachian State University. His main areas of interest include policing, community policing, race and crime, and crime mapping. He has published several articles and book chapters in the areas of community policing, spatial aspects of crime, and theories of crime. Roh is a former Commander and Chief Officer assigned to the Crime Prevention Division, Criminal Investigation Unit, and Combat Police Force Unit in Busan, South Korea. 